\title{
PRESCHOOL:
}

Jurnal Pendidikan Islam Anak Usia Dini

Volume 1, Nomor 1, Juli-Desember 2020 Hal. 14-21

\section{PENGEMBANGAN BAHASA ANAK USIA DINI MELALUI METODE BERCERITA DENGAN BONEKA TANGAN}

\author{
Mar'atul Fatimatuz Zahro, ${ }^{1}$ Iklila Febrianti Fiorentisa, ${ }^{2}$ Aisyaroh Fatini ${ }^{3}$ \\ ${ }^{1}$ Program Studi PIAUD IAIN Jember \\ e-mail: 21fatimah.azzahra@gmail.com \\ ${ }^{2}$ Program Studi PIAUD IAIN Jember \\ e-mail: iklilafebrianti@gmail.com \\ ${ }^{3}$ Program Studi PIAUD IAIN Jember \\ e-mail: aisyarohfatini@gmail.com
}

\begin{abstract}
Language is one of the important development aspects to be developed in early childhood, because language is the main communication media so that children can become part of their social groups. The Storytelling Method is one of the giving learning experiences for early childhood by telling stories to children orally. Hand puppets are one of the games favored by early childhood, because through this game children learn to communicate, imagine, express their feelings and increase their confidence. The purpose of making this article is to discuss language development in early childhood through theories from various figures. Therefore, to develop language in children, parents and teachers can use the method of telling stories with a hand puppet.
\end{abstract}

Keywords: language development, the method of storytelling, and hand puppets.

\begin{abstract}
ABSTRAK
Bahasa adalah salah satu aspek perkembangan yang penting untuk dikembangkan pada anak usia dini, karena bahasa merupakan media komunikasi utama agar anak dapat menjadi bagian dari kelompok sosialnya. Metode Bercerita merupakan salah satu pemberian pengalaman belajar bagi anak usia dini dengan membawakan cerita kepada anak secara lisan. Boneka tangan merupakan salah satu permainan yang digemari oleh anak usia dini, karena melalui permainan ini anak belajar berkomunikasi, berimajinasi, mengespresikan perasaannya dan meningkatkan kepercayaan dirinya. Tujuan dari pembuatan artikel ini untuk membahas mengenai perkembangan bahasa terhadap anak usia dini melalui teori dari berbagai tokoh. Oleh karena itu untuk menembangkan bahasa pada anak, orang tua dan guru dapat menggunakan metode bercerita dengan boneka tangan.
\end{abstract}

Kata kunci: perkembangan bahasa, metode bercerita, dan boneka tangan. 
Setiap manusia mempunyai hak untuk mendapatkan pendidikan yang layak. Sebagaimana dinyatakan dalam Pasal 31 ayat (1) Undang-Undang Dasar 1945, yaitu: "Setiap warga negara berhak mendapatkan pendidikan". Tak terkecuali anak usia dini, mereka juga mempunyai hak untuk mendapatkan pendidikan yang layak. Bahkan berawal dari mereka lah pendidikan yang baik harus merasuk kedalam pikirannya. Artinya, masa kanak-kanak merupakan dasar bagi keberhasilan dimasa datang dan sebaliknya. Untuk itu, agar pertumbuhan dan perkembangan tercapai secara optimal, maka dibutuhkan situasi dan kondisi yang kondusif pada saat memberikan stimulasi dan upaya-upaya pendidikan yang sesuai dengan kebutuhan anak yang satu dengan lainnya.

Selanjutnya berdasarkan Undang-undang RI Nomor 20 Tahun 2003 tentang Sistem Pendidikan Nasional Bab 1, Pasal 1, Butir 14 menyebutkan bahwa Pendidikan Anak Usia Dini (PAUD) merupakan suatu pembinaan yang dilakukan sejak lahir sampai usia enam tahun. Pendidikan anak usia dini bertujuan untuk menstimulasi dan mengembangkan semua aspek perkembangan yang dimiliki anak untuk memunculkan potensi secara optimal, karena anak usia dini berada pada masa peka sehingga perlu diberikan pendidikan yang tepat. Oleh karena itu, pendidikan yang dilakukan pada anak usia dini pada hakikatnya adalah upaya memfasilitasi pertumbuhan dan perkembangan yang sedang terjadi pada diri anak. Pendidikan anak usia dini (PAUD) dalam pelaksanaannya terdapat prinsip-prinsip utama yang harus diperhatikan. Prinsip-prinsip tersebut menurut Suyadi (2014) adalah sebagai berikut: (1) mengutamakan kebutuhan anak, (2) belajar melalui bermain atau bermain seraya belajar, (3) lingkungan yang kondusif dan menantang, (4) menggunakan pembelajaran terpadu dalam bermain, (5) mengembangkan berbagai kecakapan atau keterampilan hidup (life skills), (6) menggunakan berbagai media atau permainan edukatif dan sumber belajar, (7) dilaksanakan secara bertahap dan berulang-ulang. Prinsip-prinsip tersebut harus diperhatikan guru saat melaksanakan pembelajaran dalam pendidikan anak usia dini.

Anak usia dini disebut juga sebagai masa awal kanak-kanak yang memiliki berbagai karakter atau ciri-ciri ini tercermin dalam sebutan-sebutan yang diberikan oleh para orang tua, pendidikan adan ahli psikologi untuk anak usia dini (Hurlock, 1993). Bagi orang tua, masa awal kanak-kanak merupakan usia yang sulit, karna anak-anak berada dalam proses pengembangan kepribadian. Proses ini berlangsung dengan disertai perilaku-perilaku yang kurang menarik untuk orang tua, misalnya melawan orang tua, marah tanpa alasan, takut yang tidak rasional, dan sering juga merasa cemburu.

Salah satu aspek perkembangan anak usia dini adalah bahasa. Bahasa itu merupakan rangkaian bunyi yang melambangkan pikiran, perasaan, serta sikap manusia, bahasa juga dapat dikatakan sebagai lambang (Suhartono, 2005: 8). Anak dapat belajar mengungkapkan segala bentuk perasaan dalam hatinya, anak juga dapat mengutarakan apa yang dirasakan dan diinginkannya, sehingga orang lain dapat mengetahui apa yang dirasakan anak melalui bahasa. Bahasa memungkinkan anak untuk menerjemahkan pengalaman ke dalam simbol-simbol yang dapat 
digunakan untuk berkomunikasi dan berpikir. Sejalan dengan pendapat Susanto (2011: 74) bahwa "Bahasa adalah alat untuk berpikir, mengekspresikan diri dan berkomunikasi.

Keterampilan bahasa juga penting dalam rangka pembentukan konsep, informasi, dan pemecahan masalah. Melalui bahasa pula kita dapat memahami komunikasi pikiran dan perasaan". Dengan bahasa anak dapat berinteraksi dengan orang lain dan menemukan banyak hal baru dalam lingkungan tersebut. Dengan bahasa juga anak mampu menuangkan suatu ide atau gagasan terhadap keinginannya tersebut. Bahasa merupakan hal yang pokok bagi masyarakat. Bahasa membentuk dasar persepsi, komunikasi, dan interaksi sehari-hari yang kita lakukan. Bahasa merupakan suatu sistem simbol yang mengategorikan, mengorganisasi, dan mengklarifikasi pikiran kita. Melalui bahasa, kita menggambarkan dunia dan belajar mengenai dunia. Tanpa bahasa, masyarakat dan budayanya tidak akan ada.

Pengembangan bahasa memungkinkan anak belajar memahami dan mengontrol diri sendiri. Ketika anak belajar berbicara, secara tidak disengaja mereka mengembangkan pengetahuan tentang sistem fonologi, semantik, sintaksis dan sistem pragmatik. Pengetahuan fonetik merujuk kepada pengetahuan mengenai hubungan bahasa-simbol di dalam bahasa. Fonem adalah unit linguistik terkecil berbentuk bunyi yang membentuk kata jika bergabung dengan fonem yang lain. Fonem terdiri dari bunyi-bunyi yang dianggap sebagai satu unit yang dapat dimengerti oleh pendengar. Pengetahuan anak selama masa bayi dan batita terlihat jelas ketika anak menghasilkan dan membedakan antara bunyi yang digunakan dalam bahasa ibunya untuk berkomunikasi dengan mereka yang berada di sekitarnya. Pengetahuan semantik diperoleh di dalam mempelajari simbol oral atau bahasa lain yang bermakna. Pengetahuan semantik merujuk kepada penamaan kata yang merincikan suatu konsep dan juga jaringan semantik atau skemata, yang menunjukkan hubungan timbal balik antar konsep.

Perkembangan kata-kata berkaitan dengan kemampuan linguistik secara umum dan pemahaman membaca. Anak-anak dengan kosa kata yang lebih banyak dan lebih berkembang mempunyai lebih banyak pilihan untuk mengekspresikan apa yang ingin mereka katakan dan sehingga mempunyai fleksibilitas linguistik yang lebih besar. Perkembangan pengetahuan semantik juga dipengaruhi oleh kesadaran mereka akan struktur kata bahasa pada bahasa yang digunakan.

Untuk menggunakan bahasa secara efektif, perlu mengetahui bagaimana menggabungkan kata-kata untuk membentuk ekspresi yang bermakna. Setiap sistem bahasa memiliki aturan atau tata bahasa yang menentukan bagaimana kata-kata digabungkan untuk membentuk kalimat atau frasa atau ujaran yang bermakna. Aspek pengetahuan bahasa ini disebut pengetahuan sintaksis.

Pengetahuan pragmatik meliputi pengetahuan atau kesadaran terhadap keseluruhan maksud komunikasi dan bagaimana bahasa digunakan untuk memperoleh maksud tersebut. Pengetahuan pragmatik mencakup maksud pembicara, bentuk tertentu ujarannya, dan antisipasi terhadap ujaran yang mungkin diutarakan oleh pendengar titik pemilihan maksud atau tujuan dalam berkomunikasi 
dan cara bagaimana digunakan berkontribusi terhadap tingkat kemampuan komunikatif anak pada anak usia dini. Pengetahuan pragmatik juga berkontribusi terhadap kesadaran kita mengenai bagaimana berbicara dengan orang lain, bagaimana untuk berpartisipasi secara lisan dalam berbagai kondisi sosial, dan bagaimana menghasilkan percakapan yang saling berhubungan seperti di dalam narasi atau cerita. Anak-anak juga memperoleh pengetahuan pragmatik mengenai bagaimana bahasa digunakan untuk menceritakan narasi dan mengomunikasikan informasi melalui pengalamanpengalaman mereka dengan buku cerita dan buku-buku informasi. Pengetahuan ini, dapat dikembangkan oleh anak dalam kehidupan di lingkungannya, baik di rumah, dalam kehidupan bermain, dan di sekolah.

Dalam kehidupan di sekolah, pengetahuan guru tentang bahasa anak berguna untuk kepentingan perencanaan, pelaksanaan, dan dalam evaluasi pembelajaran. Dengan demikian guru hendaklah memiliki pengetahuan yang luas tentang perkembangan bahasa anak dan cara Perkembangan bahasa terbagi atas dua periode besar, yaitu: periode prelinguistik ( $0-1$ tahun) dan Linguistik (1-5 tahun). Mulai periode linguistik inilah mulai hasrat anak mengucapkan kata-kata yang pertama, yang merupakan saat paling menakjubkan bagi orang tua.

\section{METODE}

Penelitian ini merupakan library research yang bertujuan untuk mengumpulkan data dari sejumlah literatur yang relevan dengan fokus kajian, kemudian menyusun dan menganalisisnya secara mendalam. Analisis yang digunakan adalah content analysis, yang mana peneliti mengientifikasi pola dan karakteristik tertentu sesuai fokus kajian.

\section{PEMBAHASAN}

\section{Pengembangan Bahasa}

Bahasa adalah suatu alat yang digunakan untuk berkomunikasi. Hal ini berkaitan dengan pemahaman anak tentang bahasa yang ia gunakan. Sehingga dapat diamati secara langsung. Ada 4 tokoh yang memberikan pemikiran-pemikirannya tentang teori bahasa yaitu teori Gaynor, 1954, memaknai bahwa bahasa itu adalah suatu bunyi yang bisa berbicara serta dapat didengar. Teori Wardhaugh, 1982, memaknai bahasa sebagai lambang vokal yang arbiter. Teori Finichiaro, 1974, memaknai bahasa sebagai suatu budaya untuk berkomunikasi sedangkan teori Sapir, 1979 memaknai bahasa adalah suatu alat untuk mengungkapkan pikiran, perasaan dll.

Menurut Zulkifli (1995; 35-37) Periode linguistic terbagi dalam tiga fase besar. Pertama, fase satu kata. Pada fase ini anak menggunakan satu kata menyatakan pikiran yang kompleks, baik yang berupa keinginan dan perasaan tanpa perbedaan yang jelas. Misalnya kata "duduk", bagi anak dapat berarti "saya mau duduk", atau kursi tempat duduk. Orang tua baru dapat mengerti dan memahami apa yang dimaksudkan oleh anak tersebut, apabila kita tahu dalam mengembangkannya, agar kelak mereka memiliki keterampilan berbahasa yang benar, baik dalam mendengarkan, 
berbicara, membaca, maupun menulis. Pada umumnya kata pertama yang diucapkan oleh anak adalah kata benda, setelah beberapa waktu barulah disusul dengan kata kerja.

Kedua, fase lebih dari satu kata. Fase lebih dari satu kata Fase dua kata muncul pada anak berusia sekitar 18 bulan. Pada fase ini anak sudah dapat membuat kalimat sederhana yang terdiri dari dua kata. Kalimat tersebut biasanya terdiri dari pokok kalimat dan predikat, kadang-kadang pokok kalimat dengan obyek dengan tata bahasa yang tidak benar. Setelah dua kata, kemudian muncul kalimat dengan tiga kata, diikuti oleh empat kata dan seterusnya. Pada periode ini bahasa yang digunakan oleh anak tidak lagi egoisentris, dari dan untuk dirinya sendiri. Orang tua mulai melakukan tanya jawab dengan anak secara sederhana. Anak pun mulai dapat bercerita dengan kalimat-kalimatnya sendiri yang sederhana.

Ketiga, fase diferensiasi. Periode terkahir dari masa balita yang berlangsung antara usia 2.55 tahun. Keterampilan anak dalam berbicara mulai lancar dan berkembang pesat. Dalam berbicara anak bukan saja menambah kosakatanya yang mengagumkan akan tetapi anak mulai mampu mengucapkan kata demi kata sesuai dengan jenisnya, terutama dalam pemakaian kata benda dan kata kerja. Anak telah mampu mempergunakan kata ganti orang "saya" untuk menyebutkan dirinya, mampu mempergunakan kata dalam bentuk jamak awalan, akhiran, dan berkomunikasi lebih lancar lagi dengan lingkungan. Anak mulai dapat mengkritik, bertanya, menjawab, memerintah, memberitahu, dan bentuk-bentuk kalimat lain yang umum satu pembicaraan "gaya" dewasa.

\section{Metode Bercerita}

Metode bercerita merupakan salah satu metode yang banyak sekali digunakan di sekolah, terutama dalam Pendidikan Anak Usia Dini (PAUD) . Karena, dengan metode ini anak lebih tertarik untuk mendengarnya. Metode bercerita mempunyai beberapa makna atau definisi lainnya yaitu: Metode bercerita merupakan salah satu pemberian pengalaman belajar bagi anak usia dini dengan membawakan cerita kepada anak secara lisan. Cerita yang dibawakan oleh guru harus menarik, dan mengundang perhatian anak serta tidak lepas dari tujuan pendidikan bagi anak usia dini. Bila isi cerita dikaitkan dengan dunia kehidupan anak usia dini, maka mereka dapat memahami isi cerita dan mereka mendengarkannya dengan penuh perhatian serta mudah menangkapnya (Moeslichatoen, 1999).

Sedangkan metode bercerita yang dikemukakan oleh (Fadilillah, 2012) bahwa metode bercerita adalah metode yang mengisahkan suatu peristiwa atau kejadian kepada peserta didik. Kejadian atau peristiwa tersebut disampaikan kepada peserta didik melalui tutur kata, ungkapan, dan mimik wajah yang unik. Seseorang yang bercerita dengan baik akan menjadikan cerita sebagai sesuatu yang menarik dan hidup. Keterlibatan anak dalam cerita akan memberikan suasana yang segar, menarik dan unik bagi anak. 
Agar kegiatan bercerita dapat dilaksanakan secara efektif, guru harus terlebih dahulu mengetahui alasan mengapa bercerita sangat penting bagi dunia anak-anak serta manfaat dari bercerita tersebut. Bercerita merupakan alat pendidikan budi pekerti yang paling mudah dicerna oleh anak. Bercerita merupakan metode dan materi yang dapat diintegrasikan dengan dasar keterampilan lain, yaitu berbicara, membaca, menulis, dan menyimak. Dan dalam pendidikan anak usia dini (PAUD), kegiatan bercerita memberikan ruang lingkup yang bebas pada anak-anak untuk mengembangkan bersimpati dan berempati terhadap peristiwa yang menimpa orang lain. Bercerita memberi contoh kepada anak bagaimana menyikapi suatu permasalahan dengan baik. Bercerita memberikan budaya dan budi pekerti yang kuat. Bercerita memberikan ruang gerak pada anak. Bercerita mendorong anak memberikan makna bagi proses belajar. Dari pemaparan di atas dapat kita tahu manfaat dari bercerita, yaitu :

1. Membangun kontak batin antara anak dengan orang tuanya maupun anak dengan gurunya.

2. Media penyampai pesan terhadap anak

3. Pendidikan imajinasi atau fantasi anak.

4. Dapat melatih emosi atau perasaan anak.

5. Membantu proses identifikasi diri (perbuatan).

6. Memperkaya pengalaman batin.

7. Sebagai hiburan yang menarik perhatian anak,

8. Serta membentuk karakter anak.

Dengan demikian, dapat disimpulkan bahwa metode bercerita merupakan salah satu metode pembelajaran anak usia dini yang dapat memberikan manfaat positif, bagi perkembangan anak, terutama perkembangan moral, bahasa, dan sosial emosional. Terdapat beberapa macam cara bercerita yang dapat digunakan oleh guru, yaitu bercerita dengan menggunakan buku ( membacakan langsung dari buku), menggunakan ilustrasi buku gambar, bercerita dengan menggunakan papan flanel, serta bercerita dengan menggunakan boneka.

\section{Boneka Tangan}

Bercerita dengan memanfaatkan boneka sebagai alat peraga masih menjadi pilihan guru pada saat ini. Pemilihan bercerita dengan menggunakan boneka akan tergantung pada usia dan pengalaman anak. Dalam berbagai lomba mendongeng, boneka menjadi alat utama bagi peserta untuk menyampaikan cerita. Tokoh-tokoh yang diwujudkan melalui boneka berbicara dengan gerakan-gerakan yang mendukung cerita dan mudah diikuti anak. Biasanya boneka itu sendiri terdiri dari ayah, ibu, anak laki-laki, anak perempuan, kakek, nenek, dan bisa ditambahkan dengan anggota keluarga lain. Boneka tersebut menunjukkan perwatakannya masing-masing. Misalnya, ayah pekerja 
keras, ibu penyayang, anak laki-laki yang aktif, anak perempuan yang suka membantu, dan sebagainya.

Melalui boneka, anak menjadi tahu tokoh mana yang sedang berbicara. Boneka kadang juga menjadi sesuatu yang hidup dalam imajinasi anak. Bercerita dengan boneka membutuhkan persiapan yang lebih matang, terutama persiapan memainkan boneka. Keterampilan menggerakkan jari dengan lincah menjadi bagian penting dalam memainkan peran para tokoh. Salah satu alat peraga yang menarik untuk anak usia dini yaitu melalui boneka tangan dalam bercerita. Boneka tangan mengandalkan keterampilan guru dalam menggerakkan ibu jari dan telunjuk yang berfungsi sebagai tulang tangan. Boneka tangan biasanya kecil dan dapat digunakan tanpa alat bantu yang lain.

Pada dasarnya bercerita menggunakan boneka tangan memerlukan teknik tersendiri. Sebagai seorang guru, harus memperhatikan hal tersebut terlebih dahulu. Tekniknya yaitu:

1. Jarak boneka tidak terlalu dekat dengan mulut pencerita.

2. Kedua tangan harus lentur memainkan boneka, adakalanya melakukan gerakan secara bersama-sama (karena sedang angkat bicara) adakalanya diam (karena sedang menunggu giliran berbicara).

3. Antara gerakan boneka dengan suara tokoh harus sinkron. Untuk itu guru harus hafal karakter suara dan sifat masing-masing tokoh boneka. Dalam hal ini guru dituntut memiliki, sekurang-kurangnya dua karakter suara (untuk tokoh tua muda atau laki-laki dan perempuan).

4. Sedapat mungkin, selipkan nyanyian dalam cerita melalui perilaku tokoh. Ajak anakanak tersebut menyanyikan lagu bersama tokoh cerita.

5. Lakukan improvisasi melalui tokoh yang ada di dalam kelas.

6. Tutup cerita dengan membuat simpulan dan ajukan pertanyaan cerita yang berfungsi sebagai latihan bagi siswa. Hasil latihan itu berfungsi untuk mengetahui seberapa besar pemahaman yang didapatkan oleh siswa.

\section{KESIMPULAN DAN SARAN}

Bercerita dengan menggunakan boneka tangan lebih efektif untuk menarik perhatian anak, sehingga penyampaian isi atau pesan moral yang ada dalam cerita akan lebih mudah tersampaikan dengan begitu, perkembangan bahasa anak juga akan lebih terasah ketika anak lebih fokus dalam mendengarkan cerita yang kita bawakan.

Para guru dan orang tua diharapkan dapat menerapkan metode bercerita dengan boneka tangan ini untuk meningkatkan perkembangan bahasa anak usia dini

\section{DAFTAR PUSTAKA}


Preschool, Vol. 01, No. 01, Juli-Desember 2020, Hal. 14-21

Beverly, Otto. 2015. Perkembangan Bahasa Pada Anak Usia Dini. Jakarta: Kencana Prenada Media Group.

Depdiknas. 2003. Undang-Undang Nomor 20 Tahun 2003 tentang Sistem Pendidikan Nasional, Jakarta: Depdiknas

Fadillah, Muhamad. 2012. Desain pembelajaran PAUD. Yogjakarta: Ar Ruzz Media.

Indrijati, Herdiana. dkk. 2016. Psikologi Perkembangan dan Pendidikan Anak Usia Dini Sebuah Bunga Rampai. Jakarta: Kencana Prenada Media Group.

Moeslichatoen. 1999. Metode Pengajaran di Taman Kanak-Kanak. Jakarta: Depdikbud

Susanto, Ahmad. 2011. Perkembangan Anak Usia Dini. Jakarta: Kencana Prenada Media Group.

Zubaidah, Enni. 2004. "Perkembangan Bahasa Anak Usia Dini dan Teknik Pengembangannya di Sekolah, Cakrawala Pendidikan Th. XXIII, No. 3 